\title{
PERANCANGAN APLIKASI SISTEM INFORMASI DATA PRODUKSI PADA PT SHIROKI INDONESIA BERBASIS JAVA NETBEANS
}

\author{
Muhammad Bahtiar ${ }^{1}$, Nahot Frastian ${ }^{2}$, Santy \\ Handayani $^{3}$ \\ Program Studi Informatika ${ }^{1}$, Program Studi Informatika ${ }^{2}$, Program \\ Studi Informatika ${ }^{3}$ \\ Fakultas Teknik dan Ilmu Komputer ${ }^{1}$, Fakultas Teknik dan Ilmu \\ Komputer ${ }^{2}$, Fakultas Teknik dan Ilmu Komputer ${ }^{3}$ \\ Universitas Indraprasta PGRI ${ }^{1}$, Universitas Indraprasta PGRI ${ }^{2}$, \\ Universitas Indraprasta PGRI ${ }^{3}$ \\ muhammadbahtiar72@gmail.com¹, nahotfrastian@gmail.com², \\ $\underline{\text { santyhandayani1@gmail.com }}{ }^{3}$
}

\begin{abstract}
Abstrak: Perancangan Aplikasi Sistem Informasi data produksi, bertujuan untuk mempermudah dalam mengelola data produksi yang terdapat pada PT. Shiroki Indonesia, sehingga pendataan menjadi efektif, efisien, tepat guna, dan dapat membantu menyelesaikan permasalahan yang berkenan dengan pengelolaan data produksi PT. Shiroki Indonesia. Metode penelitian yang digunkan untuk perancangan aplikasi data produksi ini adalah metode penilitian kualitatif dan metode pengumpulan data dengan cara pengenalan langsung (observasi). Selain itu penulis juga melakukan penelitian dengan metode kepustakaan berdasarkan refrensi dan berbagai media yang memuat informasi yang dibutuhkan, menganalisa kebutuhan, perancangan, pengujian, dan implementasi sistem. Perancangan Aplikasi data produksi ini tercipta dengan dukungan bahasa pemrograman Java dan database MySql
\end{abstract}

Kata kunci: komponen; memformat; gaya; styling; masukkan

\begin{abstract}
Designing Production Data Information System Application, aims to make it easier to manage production data contained in PT. Shiroki Indonesia, so that the data collection becomes effective, efficient, effective, and can help solve problems that are pleased with the management of PT. Shiroki Indonesia. The research method used for the design of production data applications is a qualitative research method and data collection methods by direct recognition (observation). In addition, the authors also conduct research with library methods based on references and various media that contain information needed, analyze needs, design, test, and implement systems. The design of this production data application was created with the support of the Java programming language and MySql database
\end{abstract}

Keywords: Design of Information System Application, Production Data, Java

\section{PENDAHULUAN}

Dalam perkembangan teknologi informasi dan ilmu komputer dirasakan semakin maju dengan pesat terutama teknologi informasi, sistem informasi memiliki peranan yang sangat penting dalam usaha menciptakan kemajuan disemua bidang kehidupan manusia. Dengan adanya sistem informasi telah banyak dirasakan kemudahan dalam mendapatkan informasi yang cepat, tepat dan akurat.

Ciptaan disebarluaskan di bawah Lisensi Creative Commons Atribusi 4.0 Internasional. 
Perkembangan teknologi ilmu komputer pada saat ini semakin maju, sehingga manusia dalam mengerjakan setiap pekerjaan selalu membutuhkan komputer. Komputer memiliki peranan yang sangat vital dalam pemecahan masalah khusus dalam pengolahan data, karena komputer memiliki akurasi yang tinggi dalam pemrosesan data, sehingga dapat mempermudah pekerjaan manusia.

Adanya sistem komputer sangat membantu dalam pemecahan masalah terutama dalam hal pengolahan data. Penggunaan komputer juga dapat dijadikan alat untuk mencapai tujuan dan mencari kemudahan dalam melakukan suatu proses pekerjaan, terutama yang melibatkan banyak data. Hampir disemua instansi-instansi baik yang bersifat negeri maupun swasta menggunakan sistem komputer.

Pendataan produksi pada perusahaan sangatlah penting, khususnya untuk perusahaan yang bergerak dibidang manufaktur, dimana di setiap kegiatan produksinya harus selalu termonitor hasil produksinya, waktu produksi yang diperlukan, material apa saja yang dipergunakan saat produksi dan kendala- kendala yang ada saat proses produksi berlangsung.

Kegunaan data produksi adalah sebagai dasar evaluasi hasil produksi untuk mengetahui apakah target produksi dapat tercapai atau tidak, sehingga bila tidak tercapai, tindakan apa yang harus dilakukan, dan faktor apa yang mempengaruhi proses produksi tidak mencapai target. Kegunaan lainnya ialah sebagai suatu dasar perencanaan target produksi agar perencanaan sesuai dengan kemampuan produksi yang ada, sehingga bisa mencegah perencanaan yang ambisius dan sulit tercapai. Kemampuan yang dimaksud adalah kemampuan orang dalam proses produksi, kemampuan mesin, serta adanya masalah dalam proses produksi.

Pengambilan data produksi ini sendiri dilakukan secara manual memiliki banyak kekurangan, seperti data yang tidak valid ketika data yang masuk salah, terjadinya kesalahan pembuatan barang yang dipakai untuk produksi dari bagian produksi lainnya karena kesalahan memberi informasi data hasil produksi. Kekurangan lain dari pengambilan data secara manual adalah hilang atau rusaknya data yang ada. Kekurangan lain adalah kurangnya efisiensi dan efektifitas pada pengolahan data produksi.

PT Shiroki Indonesia merupakan perusahaan manufaktur yang memproduksi spare part kendaran roda empat asal Jepang yang memiliki banyak data-data produksi yang harus terorganisir dengan baik terutama. Dalam pelaksanaannya saat ini PT Shiroki Indonesia masih menggunakan sistem manual. Hal ini memungkinkan terjadinya keterlambatan informasi, sulit mencari data produksi ketika sedang dibutuhkan karena penyimpananya masih berupa tumpukan kertas dan banyak kesalahan dalam informasi mengenai data produksi.

Dengan permasalahan diatas penulis merasa tertarik melakukan penelitian dengan judul Perancangan Aplikasi Sistem Informasi Data Produksi Pada PT. Shiroki Indonesia Berbasis Java Net Beans.

\section{LITERATUR DAN METODE}

Peneliti melakukan penelitian langsung pada PT. Shiroki Indonesia literatur dan metode penelitian terlebih dahulu untuk menjadi acuan atau dasar mengembangkan suatu hasil penelitian. Yaitu :

\subsection{Perancangan}

Perancangan adalah suatu kegiatan yang memiliki tujuan untuk mendesain sistem yang baru, yang dapat menyelesaikan masalah- masalah yang dihadapi perusahaan yang diperoleh dari pemilihan alternatif sistem yang terbaik (Al-Bahra Bin Ladjamudin 2011:49).

\subsection{Sistem}

Sistem adalah suatu jaringan kerja dari prosedur-prosedur yang saling berhubungan, berkumpul bersama-sama untuk melakukan kegiatan atau untuk melakukan sasaran tertentu (Hutahaean, 2014).

\subsection{Informasi}

Menurut Agus Mualyanto (2009:20) Informasi adalah data yang diolah menjadi bentuk yang lebih berguna dan lebih bearti bagi yang menerimanya, sedangkan data merupakan sumber informasi yang menggambarkan suatu kejadian yang nyata.

\subsection{Java}

Bahasa Java merupakan Menurut Wahana Komputer (2015:2) menyatakan bahwa "java merupakan bahasa pemrograman tingkat tinggi yang memiliki karakteristik simple, object-oriented, distributes, interpreted, dan memilikai performa yang tinggi. Bahasa pemrograman java merupakan compiler sekaligus interpreter, di mana sebagai compiler program yang telah dibuat akan diubah menjadi java bytecodes. 
Dalam bahasa pemrograman java, seluruh code pertama kali ditulis dalam file text biasa yang akan berubah manjadi ekstensi .java. lalu seluruh file source tersebut akan di compile menjadi bytecode dengan ekstensi class oleh Java Compiler".

Java lahir karena ketidak puasan seorang insinyur di SUN Micro System bernama James Gosling. Ia tidak puas dengan compiler $\mathrm{C}++$ (yang ia gunakan untuk membuat software diembed pada peralatan elektronik) karena dinilai terlalu banyak menghasilkan bug, biaya besar, dan sangat bergantung pada platform. Gosling merasa perlu membuat compiler baru sebagai solusi terhadap sejumlah kelemahan pada C++ tersebut" (Miftahul Huda, 2010:23).

\subsection{Database}

Database atau basis data terdiri dari 2 kata, yaitu basis dan data. Basis kurang lebih dapat diartikan sebagai markas atau gudang, tempat bersarang/berkumpul. Sedangkan data adalah representasi fakta dunia nyata yang mewakili suatu objek seperti manusia (pegawai, siswa, pembeli, pelanggan), barang, hewan, peristiwa, konsep, keadaan, dan sebagainya, yang mewujudkan dalam bentuk angka, huruf, simbol, teks, gambar, bunyi atau kombinasinya" (Fathansyah, 2012:2).

2.6 MySQL

Mysql merupakan salah satu perangkat lunak basis data yang paling banyak digunakan di dunia karena, mysql dapat digunakan secara gratis dan memiliki kemampuan pengolahan data yang baik.

Menurut Andi Kristanto (2010:12), mengatakan bahwa MYSQL adalah sebuah perangkat lunak sistem manajemen basis data SQL atau DBMS yang multithread dan multi-user. MYSQL adalah Relational Database Management System (RDBMS) yang didistribusikan secara gratis dibawah lisensi GPL (General Public License). Setiap orang bebas untuk menggunakan MYSQL."

"Database MySQL dapat dibuat dengan tampilan GUI (Graphical User Interface) menggunakan aplikasi Web Server XAMPP pada fitur PhpMyadmin” (Yuniar Supardi,2015:32).

\section{METODE}

\section{A. Metode Penelitian}

Metode penelitian yang digunakan oleh penulis dalam tugas akhir ini adalah metode kuantitatif yaitu metode penelitian berdasarkan pada fakta dan menggunakan analisis perbandingan dengan tujuan untuk mendapatkan pola atau model matematis, pembuktian teoritis dan hipotesis yang dibentuk peneliti.

Metode penelitian kuantitatif memiliki cakupan yang sangat luas. Secara umum, metode penelitian kuantitatif dibedakan atas dua dikotomi besar, yaitu eksperimental dan noneksperimental. Dalam penyusunan tugas akhir ini penulis menerapkan kategori eksperimental yang merupakan suatu percobaan yang dirancang secara khusus guna membangkitan data yang diperlukan untuk menjawab pertanyaan penelitian. Penelitian yang menggunakan rancangan percobaan dianggap sebagai jenis penelitian yang paling diinginkan oleh seorang peneliti. Yang dimaksud dengan percobaan ialah bagian penelitian yang membandingkan dua kelompok sasaran penelitian. Satu kelompok diberi perlakuan khusus tertentu dan satu kelompok lagi dikendalikan pada suatu keadaan yang pengaruhnya dijadikan sebagai pembanding.

\section{B. Metode Pengumpulan Data}

Metode pengumpulan data yang dilakukan oleh penulis untuk mendapatkan data-data serta informasi untuk mendukung penempurnaan hasil dari peneltian ini antara lain :

\section{a. Studi Pustaka}

Dilakukan dengan cara mencari informasi dari berbagai literatur yang berhubungan dengan Perancangan Aplikasi Sistem Informasi Enterprise Data Produksi Pada PT. Shiroki Indonesia.

\section{b. Metode Wawancara}

Metode wawancara adalah penelitian yang dilakukan dengan mencatat semua data-data yang dibutuhkan dari narasumber, kemudian diubah menjadi sebuah informasi yang lebih akurat demi suksesnya 
program yang dibuat.

\section{c. Metode Observasi}

Melakukan survei untuk mengetahui masalah apa yang bisa dikerjakan sesuai dengan materi ilmu yang dimiliki peneliti dan untuk mengetahui proses pendataan data produksi yang ada di PT. Shiroki Indonesia.

\section{Langkah-Langkah Pengembangan Sistem}

\section{a. Identifikasi}

Penulis mengidentifikasi masalah-masalah yang ada pada Pusat Pelatihan Kerja Pengembangan Industri mulai dari proses adsensi peserta pelatihan, monitoring data peserta pelatihan hingga menjadi laporan yang dilaporkan kepada pimpinan.

\section{b. Analisis dan pengumpulan data}

Analisis sistem adalah kegiatan untuk melihat sistem yang sudah berjalan, melihat bagian mana yang bagus dan tidak bagus, dan kemudian mendokumentasikan kebutuhan yang akan dipenuhi dalam system yang baru. Sedangkan pengumpulan data dan informasi berfungsi sebagai masukan untuk sistem dan untuk memperoleh data yang berhubungan dengan tugas akhir ini. Pengumpulan data dilakukan dengan cara interview kepada narasumber. Apabila sebuah sistem yang dirancang benar-benar baru maka pada langkah ini pegembangan bias menekankan kepada studi kelayakan dan definisi sistem.

\section{c. Perancangan sistem}

Perancangan sistem merupakan upaya untuk mengontruksi sebuah sistem yang memberikan kepuasan akan spesifikasi kebutuhan fungsional, memenuhi target, memenuhi kebutuhan secara implisit atau eksplisit dari segi performansi maupun penggunaan sumber daya, kepuasan batasan pada proses desain dari segi biaya, waktu dan perangkat.

Beberapa proses dalam perancangan sistem yaitu pembuatan dokumen flow, sistem flow, context diagram, data flow diagram, entinity relation diagram, struktur table, dan design input output untuk dibuat aplikasi selanjutnya.

\section{d. Desain aplikasi}

Pada tahap ini dilakukan perancangan struktur data, karakteristik antarmuka, dan tampilan layar dari sistem yang akan dirancang agar menarik.

\section{e. Pengkodean dan pengujian sistem}

Sebelum sistem dijalankan maka harus melaksanakan pembuatan dengan perintah kode program. Setelah proses pengkodean selesai maka akan dilakukan proses pengujian terhadap program yang dirancang unutk mengetahui apakah program sudah berjalan dengan baik dan benar sesuai dengan desain yang direncanakan sebelumnya.

\section{f. Evaluasi sistem}

Evaluasi yang ditunjukan sebagai bagian dari tahap terakhir perancangan sistem biasanya dimaksudkan untuk pembahasan. Evaluasi dilakukan di setiap tahap. Kerja sistem biasanya berulang, ketika penulis menyelesaikan satu tahap pengembangan sistem akan berlanjut ke tahap berikutnya. Penemuan suatu masalah bisa memaksa penulis kembali ke tahap sebelumnya dan memodifikasinya. Karena selama tahap pengujian, bisa ditemukan program tidak dapat berjalan sebagaimana mestinya, bisa disebabkan kodenya salah untuk mendukung bagian perancangan sistem tertentu atau desain tidak lengkap.

\section{g. Implementasi}

Implementasi dan pengkodean adalah proses menterjemahkan dokumen hasil desain basis-basis perintah bahasa pemrograman komputer, Semakin baik hasil analisis dan desain yang dilakukan, maka proses pengkodean ini akan lebih mudah digunakan.metode Analisis

yang Object Oriented Analisis (OOA). OOA melihat masalah berdasarkan objek pengguna sistem, dengan $O O A$ dapat dibuat objek permodelan sistem yang berjalan 


\section{HASIL DAN PEMBAHASAN}

Berdasarkan hasil penelitian yang peneliti lakukan, berikut proses sistem berjalan untuk sistem data produksi di PT. Shiroki Indonesia :

1. Team Leader memberikan form kertas pendataan produksi ke operator.

2. Setelah menerima form kertas pendataan produksi, operator mengisi data hasil produksi ke form kemudian memberikannya kembali ke Team Leader.

3. Team Leader melakukan rekapitulasi form yang diisi oleh operator, kemudian memindahkannya ke form laporan produksi yang berada di papan informasi yang berada didepan mesin.

4. Team leader menyerahkan form kertas pendataan produksi ke Group Leader.

5. Group Leader menerima form kertas pendataan produksi setiap hari sebagai data laporan produksi setiap harinya dan untuk mengetahui pencapain produksi setiap harinya.

6. Group Leader menyerahkan form kertas pendataan produksi ke admin untuk di input ke Microsoft Excel.

7. Group Leader membuat laporan produksi setiap seminggu sekali untuk laporan ke Manager.

8. Manager mengecek laporan hasil produksi setiap seminggu sekali.

Berdasarkan analisis yang telah dilakukan oleh peneliti, sistem informasi data produksi pada PT.Shiroki Indonesia yang sedang berjalan saat ini, dapat disimpulkan bahwa Sistem pendataan produksi yang berjalan saat ini dilapangan masih bersifat semi komputerisasi, yaitu masih menggunakan form kertas yang digunakan setipa hari kerja. Penyimpanan data yang masih sangat manual, yaitu menyimpan form-form kertas menjadi satu ke dalam map, hal ini menyebabkan adanya peluang kehilangan ataupun tercampurnya data,karena media penyimpanannya yang kurang baik. Pembuatan laporan menjadi tidak efektif dan data yang dihasilkan belum akurat karena masih ada kesalahan pada saat proses pendaatan produksi. Lamanya proses pencarian data, karena data yang disimpan tidak memiliki kata kunci yang spesifik untuk menemukan data produksi.

Maka peneliti memberikan alternatif penyelesaian masalah, dengan merancang sebuah aplikasi sistem informasi data produksi pada PT. Shiroki Indonesia berbasis Java Net Beans, agar proses penginputan data dapat terkomputerisasi dan data dapat disimpan di database, sehingga Team Leader bisa langsung bisa menginput dara produksi ke aplikasi desktop. Kemudian Group Leader mengecek dan meng-update hasil input-an Team Leader cukup leawat aplikasi desktop, Yang nantinya Group Leader hanya memilih data mana yang akan dilakukan proses rekapitulasi,sesuai yang diminta atasan. Dari semua hal ini peniliti berharap dapat memudahkan karyawan dalam pembuatan, pencarian, pengecekan, meng-update dan membuat laporan data produksi.

Berikut ini adalah gambaran sistem yang diusulkan pada pengolahan data produksi pada PT.Shiroki Indonesia secara keseluruhan dalam bentuk diagram konteks.

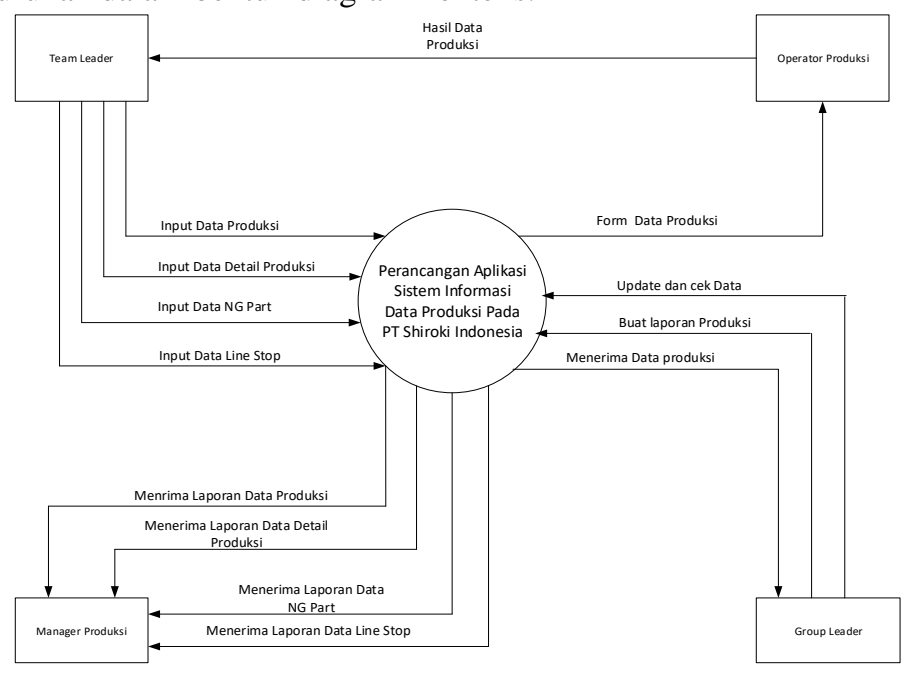

Gambar 1. Diagram Konteks Sistem Pengolahan Data

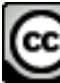




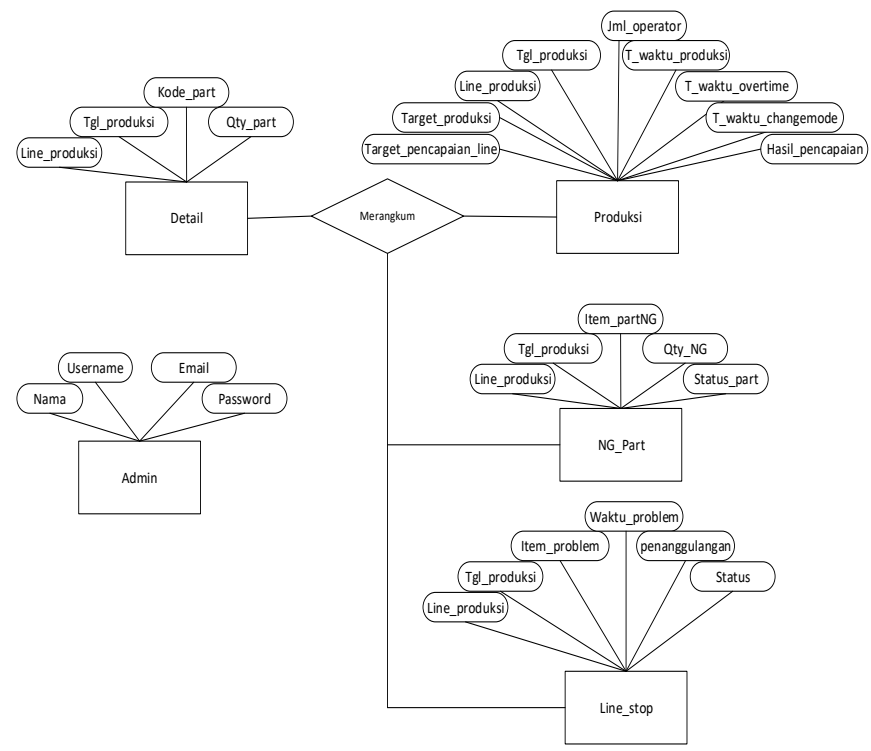

Gambar 2. Entity Relationship Diagra m(ERD)

Selanjutnya peneliti membuat aplikasi menggunakan java netbeans edisi 8.2 berbasis desktop dan menggunakan basis data $M y S Q L$. Berikut ini adalah tampilan dari aplikasi sistem informasi data produksi pada PT.Shiroki Indonesia.

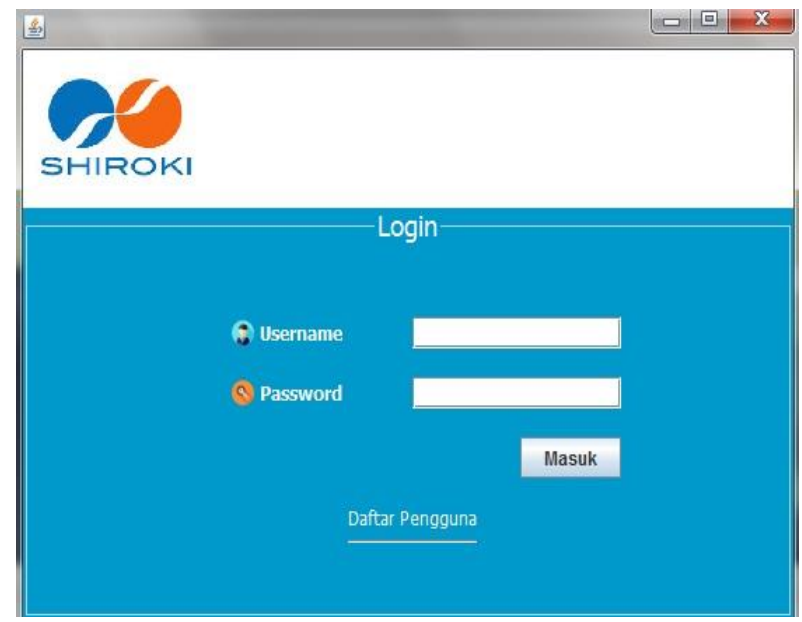

Gambar 3. Tampilan Layar Login

Layar diatas merupakan menu login, rancangan ini terdapat pada awal program,. menu login digunakan sebagai kata kunci sebelum kita memasuki program utama. Program ini tidak sembarangan orang dapat mengakses dan kerahasiaan tetap terjaga dengan baik. 


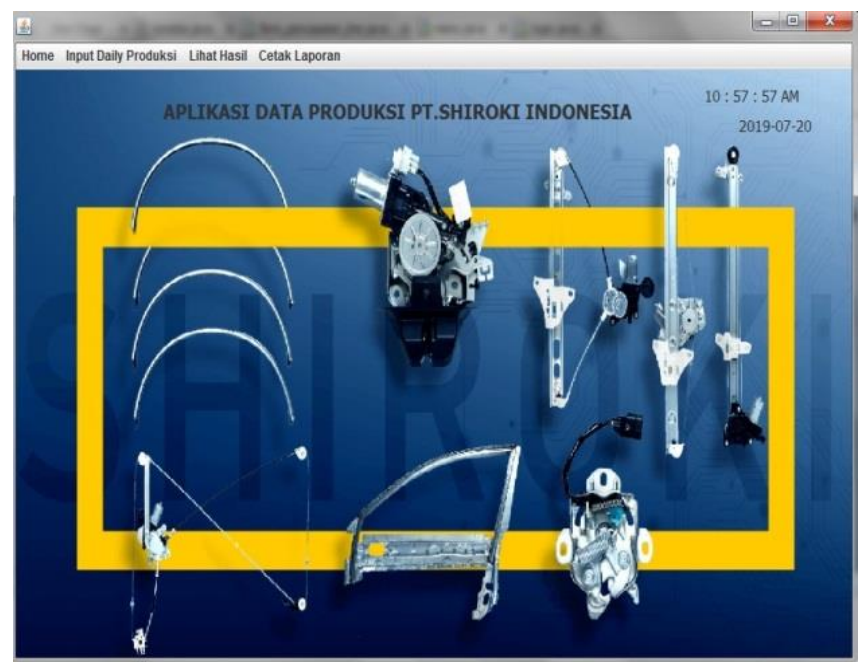

Gambar 4. Tampilan Layar Menu Utama

Layar diatas adalah tampilan menu utama Perancangan Aplikasi Sistem Informasi Data Produksi pada PT.Shiroki Indonesia. Menu utama ini digunakan untuk menjalankan form- form yang terdapat didalam aplikasi. Pada menu utama ini juga terdapat background barang- barang yang diproduksi di PT.Shiroki Indonesia. Di menu utama ini terdapat layar menu utama button Home fungsinya untuk kemabali ke layar utama, selanjutnya terdapat menu button Input Daily Produksi, di menu ini terdapat 4 form yaitu form input produksi, form Detail Produksi, form NG Part, dan Form Line Stop. Menu button selanjutnya adalah Lihat hasil, menu ini fungsinya untuk melihat hasil dan mengupdate data.Dan menu button yang terakhir adalah cetak laporan.

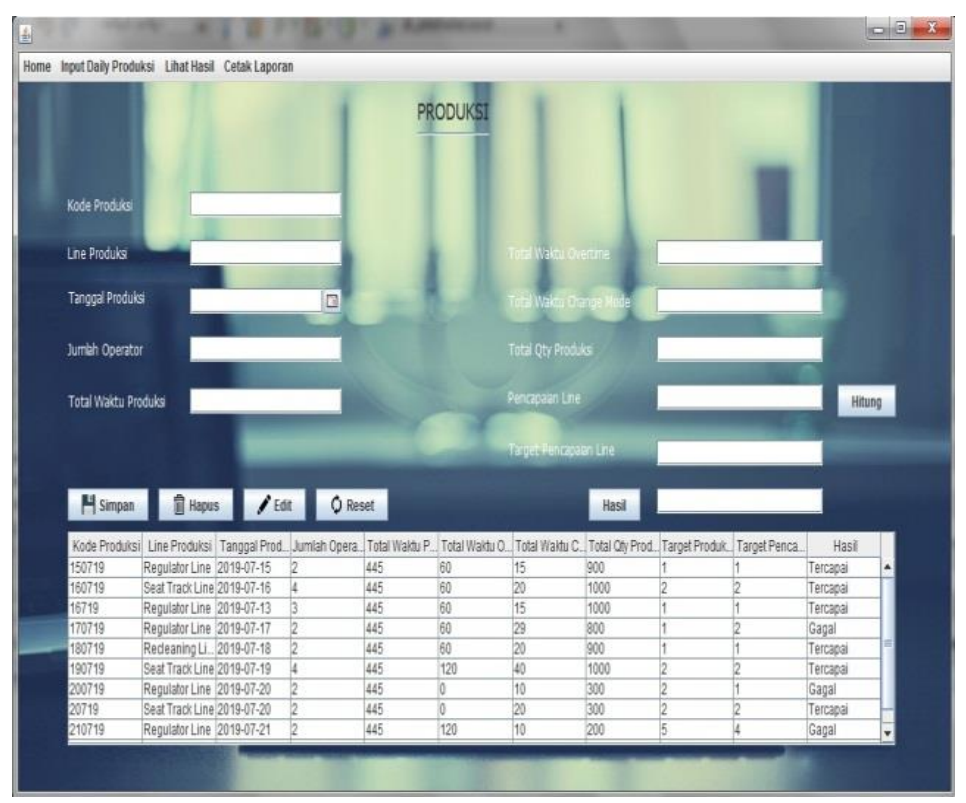

Gambar 5. Tampilan Form Input Produksi 
Tampilan layar diatas adalah tampilan form untuk input data produksi yang akan digunakan Team Leader untuk meng-input hasil data produksi yang diberikan operator. Diform ini akan terlihat apakah sebuah Line produksi akan tercapai atau gagal.

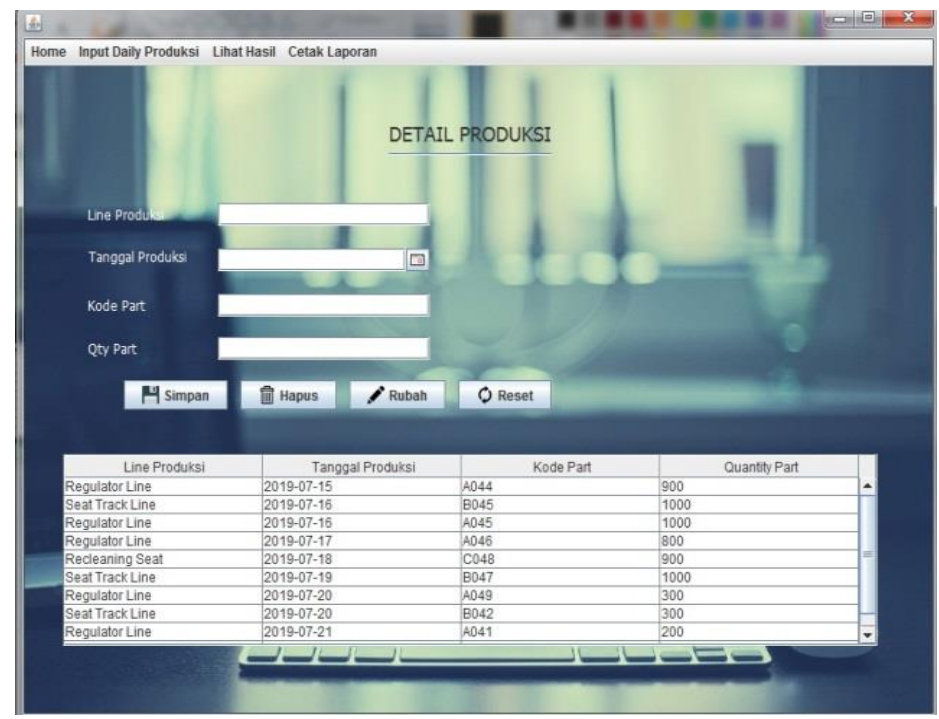

Gambar 6. Tampilan Form Input Detail Produksi

Tampilan ini merupakan form untuk input detail produksi, maksud dari kata detail diform ini dalah ada detail- detail jenis part yang diproduksi disetiap Line Produksi.

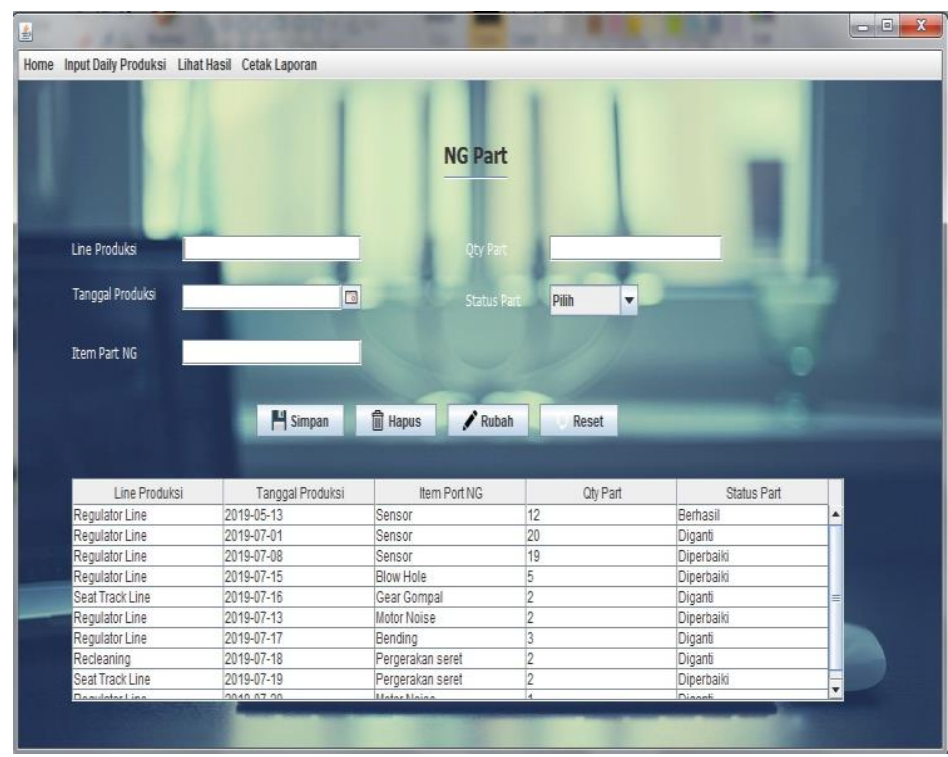

Gambar 7. Tampilan Form Input NG Part 
Tampilan ini merupakan form untuk input data barang yang rusak saat proses produksi dan status barang itu bisa diperbaiki atau tidaknya.

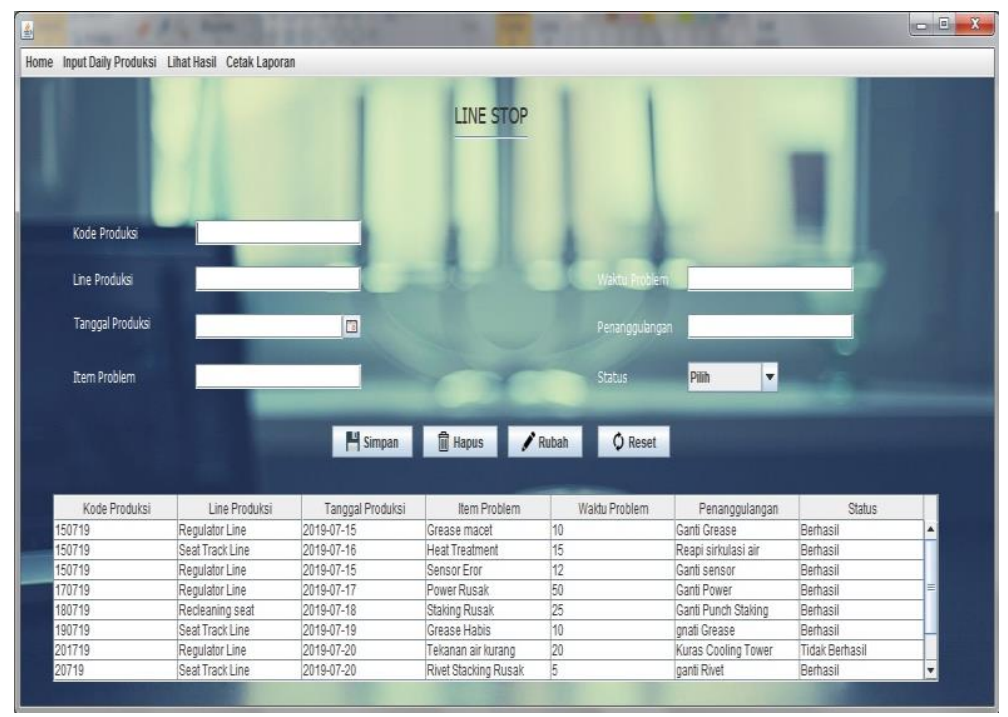

Gambar 8. Tampilan Form Input Line Stop

Tampilan diatas merupakan form untuk input data problem mesin yang mengakibatkan proses produksi berhenti.

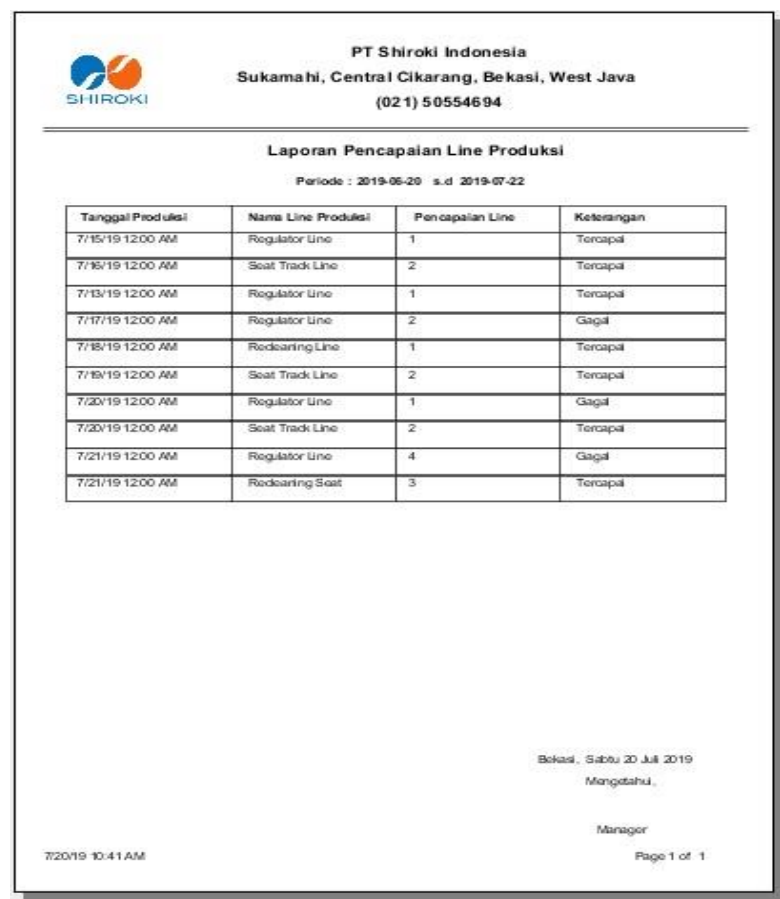

Gambar 9. Tampilan Cetak Laporan Pencapaian Line Produksi 


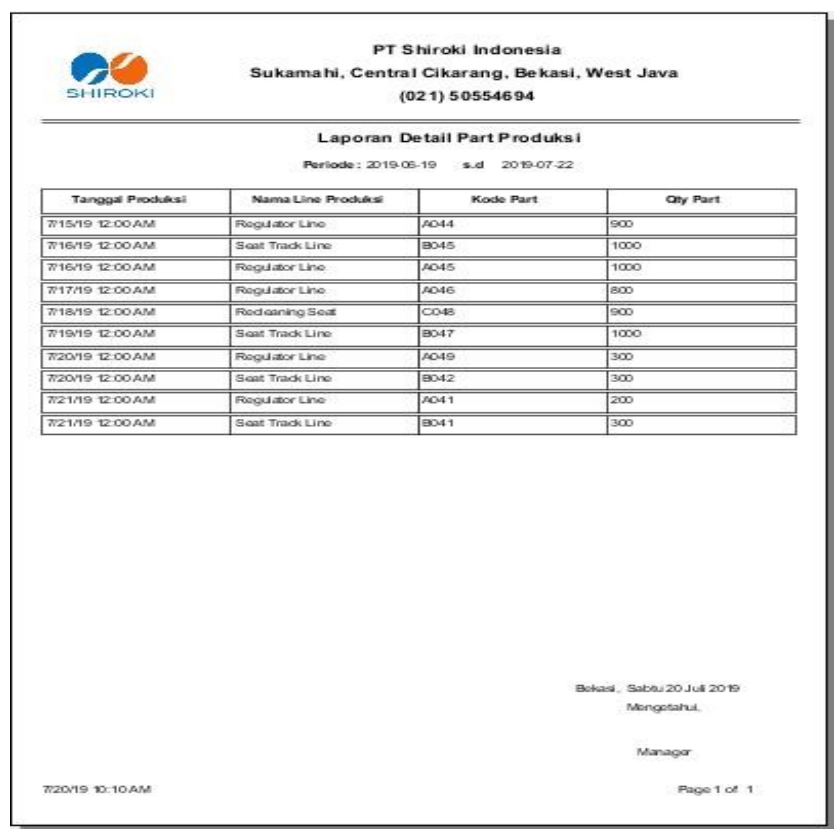

Gambar 10. Tampilan Cetak Laporan Detail Part Produksi

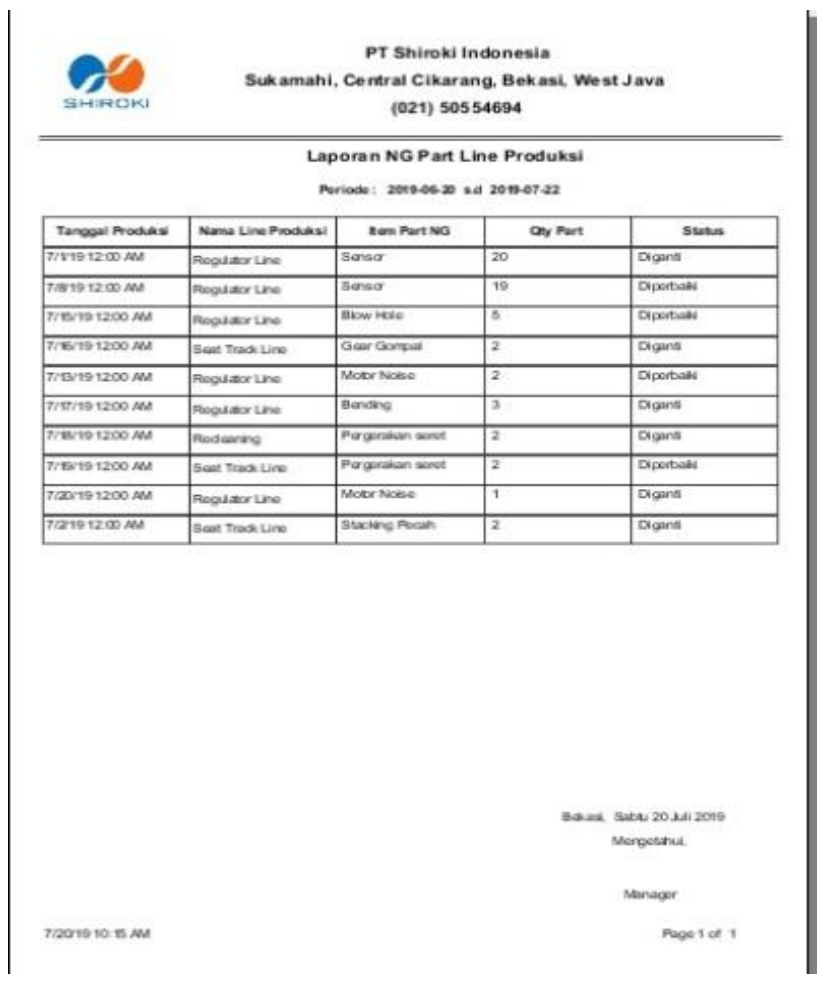

Gambar 11. Tampilan Cetak Laporan NG Part Produksi 


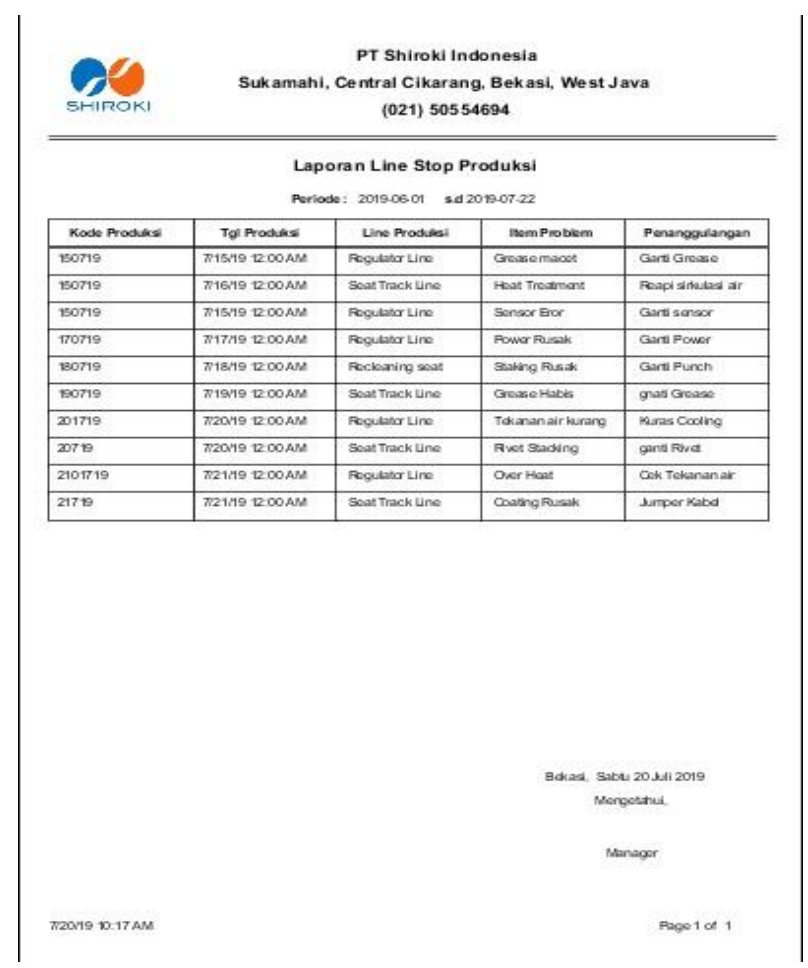

Gambar 12. Tampilan Cetak Laporan $N G$ Part Produksi

Tampilan diatas adalah tampilan cetak Laporan Pencapaian Line Produksi, Laporan Detail Produksi, laporan $N G$ Part (barang rusak),dan Laporan Line Stop. Laporan ini dibuat untuk dilaporkan ke Manager.

\section{KESIMPULAN}

\section{a. Simpulan}

Adapun kesimpulan yang diperoleh dari pembuatan Aplikasi Sistem Informasi Data produksi pada PT. Shiroki Indonesia, adalah sebagai berikut:

1. Pengolahan data produksi sudah terkomputerisasi.

2. Dengan aplikasi ini maka karyawan jadi lebih mudah dalam melakukan pendataan.

3. Dengan adanya aplikasi ini, maka efektifitas karyawan dala melakukan proses pendataan meningkat, kesalahan berulang juga bisa dihilangkan, dan pengolahan data produksi menjadi lebih cepat, tepat, data yang dihasilkan selalu update. Dari hal ini semua PT. Shiroki Indonesia bisa mengefisienkan waktu karyawannya dalam bekerja, khususnya dala pengolahan data produksi.

\section{b. Saran}

Sejalan dengan sistem usulan yang peniliti buat, maka demi tercapainya tujuan dan sasaran yang diharapkan, maka peneliti dapat memberikan saran sebagai berikut:

1. Aplikasi sistem informasi data produksi pada PT. Shiroki Indonesia haruslah didukung oleh sistem yang disiplin dan penggunaan yang baik sesuai ketetapan bersama agar dapat berjalan dengan semestinya.

2. Pengamanan data dengan melakukan backup data yang penting harus dilakukan secara berkala agar data tersebut dapat terhindar dari kerusakan.

3. Dengan adanya perancangan sistem aplikasi enterprise data produksi ini diharapkan dapat memicu pengembang lainnya untuk lebih berinovasi dalam merancang sistem selanjutnya.

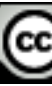

Ciptaan disebarluaskan di bawah Lisensi Creative Commons Atribusi 4.0 Internasional. 


\section{Journal of Information System, Applied, Management, Accounting and Research.}

http://journal.stmikjayakarta.ac.id/index.php/jisamar, jisamar@stmikjayakarta.ac.id , jisamar2017@gmail.com e-ISSN: 2598-8719 (Online), p-ISSN: 2598-800 ( Printed), Vol. 5, No.1 Februari 2021

\section{REFERENASI}

[1] Ladjamudin, B. Al Bahra. (2011). Analisis dan Desain Informasi. Bandung: Alfabeta.

[2] Hutahaen, Japerson. (2014). Konsep Sistem Informasi. Yogyakarta: Deepublish

[3] Mulyanto, Agus. (2009). Sistem Informasi Konsep dan Aplikasi. Yogyakarta: Pustaka Pelajar.

[4] Komputer, Wahana. (2015). PAS: Membangun Sistem Informasi dengan

[5] Java Net Beans dan MySql. Yogyakarta: Andi.

[6] Huda, Miftahul. (2010). Membuat Aplikasi Database dengan Java,MySql,dan NetBeans. Jakarta: PT Elex Media Kumputindo.

[7] Fatansyah. (2012). Basis Data. Bandung: Informatika.

[8] Kristanto, Andi. (2010). Menguasi PHP dan MySql Dengan Mudah Cepat. Kalten: Cable Book.

[9] Supriadi, Yuniar. (2015). Belajar Coding Android Bagi Pemula. Jakarta: PT Elex Media Kumputindo. 